\title{
Tragic Imagery of War in Roman Visual Culture
}

\author{
Lindsay Prazak
}

\begin{abstract}
In this paper, the scope of Roman attitudes towards warfare is examined through an analysis of Roman artwork and inscriptions in victory monuments. Due to the integral nature of warfare to Roman society, the portrayal of victorious campaigns was essential to the maintenance of the Roman perception of their own indomitable nature. This paper argues that this inherent reinforcing of Roman attitudes was especially important in the wake of the various civil wars and related disputes of the last century of the Republic, and undertakes this analysis with a special emphasis on the portrayal of the conquered to examine the subtleties of perspective towards Roman warfare.
\end{abstract}

"Visual imagery...gives insight into people's values and imagination that often cannot be apprehended in literary sources."

Paul Zanker ${ }^{1}$

Warfare was an integral part of Roman society, dating back to the semi-mythological founding of the city by the progeny of Mars: Romulus and Remus. After decades of civil war, and the creation of the Principate under Augustus, warfare took Roman armies to distant regions beyond the Italic peninsula and expanded borders in nearly every direction around the periphery of Rome, filling Rome with literature of laus et gloria and inscriptions on martial victory monuments. Tonio Holscher states that Roman visual culture illustrates "mentally constructed behaviour and perceptions" of war. ${ }^{2}$ In the scope of this paper, my primary focus is imagery of Roman warfare. I will look at some differences between portrayals of the conqueror, and how they interact with the conquered, and through this study hypothesize how Roman visual culture reflects attitudes towards war. In so doing, I will focus mostly on the anomalous isolated portrayal of the defeated to examine the subtleties of perspective towards Roman warfare.

Warfare was a popular subject in both verbal and visual accounts. Ancient writers, such as Tacitus and Marcus Aurelius, produced literature describing the events and aftermath of wars. Situated in a literate society with text being the source of greatest prestige, current scholarship is heavily based on the written word. Text has the capacity to give concise descriptions of events and build meaning through time; text is verbalized, written down and

\footnotetext{
${ }^{1}$ Paul Zanker, "The Power of Images in the Age of Augustus," Michigan: University of Michigan, $1990,3$.

2 Tonio Holscher, "Images of War in Greece and Rome: Between Military Practise, Public Memory, and Cultural Symbolism," Journal of Roman Studies 93 (2003), 2.
}

Constellations

Volume 2, No. 2 (Winter 2011) 
studied, and is essentially different than images through its intellectual priorities. ${ }^{3}$ Roman 'art' (henceforth, imagery or visual culture) does not function as what we know to be 'art.' Images in Rome were not necessarily set up to be admired for their aesthetic value as part of a museum catalogue. Admiration could very well be part of the viewing process, however "we must concentrate on what Romans saw, not what we see." Images functioned as a semiotic system capable of sophisticated communication through a long established set of images with culturally accepted meanings and connotations to create visually legible signs, made up of arbitrary connections between pairs of signifier and signified - the thing being represented and the concept or idea the thing denotes. ${ }^{5}$ The Roman visual semantic system is further sophisticated through use of style, context and interaction with the physical space around it; imagery creates a powerful impression through its physical presence by imposing onto or integrating into the fabric of the city or landscape, creating a specifically constructed atmosphere that imparts a sense of feeling. A semiotic system is complete in and of itself: "Roman viewers did not consult texts the moment they saw an image," but instead viewed images and visual culture as a wholly independent mode of communication.

Monumental constructions honouring martial qualities modified the cityscape of Rome as victors dedicated triumphal arches, columns and temples, such as Honos and Virtus, Mars, and Bellona. The topography of Rome was continually modified as signs of victory trumpeted across the Roman Empire in forms of imagery, reliefs, and sculptures; Rome was the showplace of victory from distant wars. In many cases, only imagery of the victorious was present, such as on the Arch of Titus. One interior frieze has a victorious procession of Roman soldiers carrying spolia of the Great Temple of Jerusalem, symbolized by the menorah. On the other side, a triumphal procession of Titus in a quadriga is crowned by Victoria. Other portrayals of the victorious include the standard martial scenes of profectio, adlocutio, adventus, liberalitas and lustratio. Though part of the crowd in each scene, the victorious emperor is distinctly shown as slightly larger, on a raised platform, or appearing closer to the viewer through higher relief. The victor is slightly removed in himself, a step above the crowd, and distinguished through his virtus.

War necessitated unbalanced power relations between victors and the defeated. Pairs of opposition, between victor and defeated, Roman and Barbarian, complete the holistic sense of warfare, and Rome was covered in imagery of victorious-defeated pairs. Bipartite representations were depicted in relief or sculpture in everything ranging from the columns of Trajan and Marcus Aurelius to victory arches of Septimus Severus and Constantine. Even on the cuirass of the Augustus of Prima Porta was there a victor-defeated pair central to the relief, showing military triumph over Parthia. The visual differences between conqueror and conquered become evident in a number of factors, most immediately through iconography. Roman soldiers are typically dressed in heavy armour, with a helmet, chain mail or cuirass, and if of particularly high rank, a chlamys. In contrast, barbarians are usually given regional attributes, such as a Phrygian cap and trousers to identify Persians. Tunics, shaggy hair and

3 Steven Hijmans, Sol: The Sun in the Art and Religions of Rome, (PhD diss., University Groningen, 2009),

${ }^{4}$ Hijmans, Sol, 32.

5 Bal \& Bryson (1991), Hijmans (2009), Holscher (2003, 2004), Kampen (1995), Mitchell (1986), Panofsky (1955).

${ }^{6}$ Hijmans, Sol, 32.

Constellations

Volume 2, No. 2 (Winter 2011) 
beards are used to represent other foreign enemies, such as the Gauls. The defeated are frequently objectified and shown as targets of scorn, especially when propped up against a trophy and largely functioned to serve as a point of contrast for the victors (plates 1,2). Roman trophies were commonly made by hanging the defeated leader's armour on a tree, creating an inhuman object of ridicule, furthering the triumph at the expense and humiliation of the conquered. This imagery uses pairs of subdued barbarians propped up against trophies, and in this position, they themselves form part of the trophy, becoming dehumanized through a spectacle of mockery.

Other key sources of differentiation are the positioning of figures and the use of space, exemplified in Roman imagery by the Alexander mosaic and the Gemma Augustae. The Alexander mosaic is from the atrium of a $2^{\text {nd }}$ century BCE house in Pompeii (Plate 3). The victorious figure is mounted and stable, appearing unfettered by the impending collision. ${ }^{7}$ In contrast, the barbarian horde is a chaotic mass, many bodies are fallen and trapped on the ground by the crowd above them. The depiction of a tangled crowd takes advantage of the use of space within the mosaic; barbarian figures are overlapping and tightly packed together--hard-pressed by imminent defeat. Although the mosaic below the charging pseudo-Alexander is lost, he appears relatively separate from the chaos, able to hold a space of his own.

In the Gemma Augustae, the positions of the figures make a stark contrast between conqueror and conquered (Plate 4). In the upper register, all figures are larger, formalized and regal, especially the two central figures of Roma and Augustus who are both majestically enthroned. The subsidiary figures all have their heads and bodies turned towards this central powerful pair, focusing attention and respect on the coronation. Spatially these figures are literally and figuratively elevated within the cameo, raised to a divine sphere of existence. This use of sharply differentiated space is confirmed through use of iconography associated with the gods, such as Augustus' divine partial nudity, Jupiter's eagle beneath his feet, and the presence of Roma and Victoria. Even within the lower register, the use of space is subtly applied to separate the victors from the defeated. The soldiers are shown as commanding authority, loftily standing above the incapacitated barbarians, who sit on the ground. The soldiers' bodies are in positions of authority, triumph and duty. To the left, they erect a trophy, signifying a complete victory, and to the right, the soldiers are figures of domination, subduing the prisoners. In contrast, the two pairs of barbarians, on or near the ground, are posed with bodily gestures of defeat such as motions of supplication and helplessness (Plate 1).

Perhaps one of the most imperative distinguishing factors in Roman imagery is style. In combination with iconography, position, and rendering of space, style has the potential to create different degrees of expression, emotion, and mood. All of these lend to the holistic atmosphere the image creates and the voice that speaks to viewers. In the Alexander mosaic, the victorious figure is shown with a blank, emotionless face, typical of the Classical style; the figure exudes calmness and control and is unfettered by the collision. The Persians, taking up most of the mosaic, are shown as subordinate enemies through their anguished,

7 The triumphant figure is likely a portrait of the Roman house owner, "quoting" the visual imagery of Alexander the Great.

Constellations

Volume 2, No. 2 (Winter 2011) 
contorted faces. Holscher goes into great detail describing the use of emotion, expression and chaos within facial features as key elements of the Hellenistic style--a style that is effectively used in displaying a sense of the pathos of war. ${ }^{8}$ The Hellenistic style was used consistently in Roman art to contribute to the subtleties of an image's connotations; another famous example is the Laocoön (Plate 16). High emotional tension is best conveyed using mimesis in the Hellenistic style, creating naturalism to mimic reality and create a specific mood based off of a representation of human emotion. It is the use of this style to represent barbarians in Roman art which is particularly revealing.

Many scholars describe the emotive barbarian functioning as a dramatic point of opposition to the triumphant (Roman), serving only to intensify the victory of Rome. Andrew Stewart explains that imagery of the defeated are "objects of sport," and describes them as figures of shame and humiliation." Shelia Dillon states that the more exaggerated suffering of barbarians, the greater and more secure in her power Rome becomes. ${ }^{10}$ Holscher gets closer to the heart of the matter in his examination of victor-defeated contrast. He looks at the pair not just in terms and implications for the victor, but further elucidates the defeated as a figure in and of itself; he looks at the barbarian--its style, portrayal and emotion--as an independent force on the Roman viewer through mimetic emotion, evoking sympathy. Holscher explains the victor is heightened to a completely different level than the defeated, therefore the greatness and admiration for the victor is not in conflict with sympathy for the defeated. ${ }^{11}$ In order to see how images of defeated barbarians functioned in Roman imagery, we must look to isolated portrayals.

Solitary depictions of defeated barbarians were much less common in Roman visual culture than either solitary victorious figures or combined victor-barbarian pairs. The most conspicuous examples are the many statues of the so-called Pergamene barbarians (Plates 515). Most of these statues are of unknown provenance, but all are believed to be unquestionably Roman copies or adaptations of $2^{\text {nd }}$ century BCE statuary and reliefs from Pergamene victory monuments of Attalos I. No original statues remain from Pergamon, so there has been a lot of scholarly debate as to the comparisons between potential originals and Roman copies, and it has been suggested that it was purely a Roman innovation to use just the barbarians. ${ }^{12}$ There is speculation about the composition of the individual barbarian statues, how they were arranged in relation to each other and if a composition included potential separate triumphal reliefs. Basing his theory on the archaeological record of Pergamene statue types, Stewart notes it is most likely that only the barbarian statues existed in Roman visual culture. ${ }^{13}$

\footnotetext{
8 Tonio Holscher, The Language of Images in Roman Art, Trans. Anthony Snodgrass and Annemarie KunzlSnodgrass, (New York: Cambridge University Press, 2004), 26.

9 Andrew Stewart, Attalos, Athens and the Akropolis: The Pergamene 'Little Barbarians' and their Roman and Renaissance legacy, (New York: Cambridge University Press, 2004) 150.

10 Shelia Dillon in S. Dillon and Katherine E. Welch, Eds, Representations of War in Ancient Rome, (New York: Cambridge University Press, 2006) 12.

${ }^{11}$ Holscher (2004), 34

12 Stewart (2006), 74.

13 Stewart (2006), 147.
} 
Even without context of the Roman replicas, there is significance in examining what we can see about the statues. Based on sculptural factors, such as technique and depth of drilling, most scholars agree that the Roman copies of the Pergamene barbarian statues date to the $2^{\text {nd }}$ century CE. The base of each figure is intact and individualized; it is clear that they were not part of a larger statue group, but existed solitarily. There is purpose in their isolation. I mentioned earlier that the outcome of Roman warfare is twofold, demonstrable through the existence of the victorious Roman and defeated barbarian. By portraying a barbarian as a defeated, isolated figure, victory is periphrastically inherent through the holistic concept of warfare. In Roman visual culture, a solitary representation of a defeated barbarian implies Roman success with little difficulty. In this way, there is no conflict of interest in portraying either a solitary victorious Roman or an isolated defeated barbarian because the integral, dichotomous pair of Roman victor-vanquished Barbarian was entrenched in Roman warfare. This theory then lends the question, why the focus on the defeated barbarian?

As the focus shifts to the isolated barbarian within the examples of Pergamene-inspired barbarian statues, the imagery of Roman warfare moves away from the normative portrayal of the victorious to the opposite end of the dichotomy. I do not presuppose that this image type was a novel creation, for Roman art was not necessarily creative. ${ }^{14}$ Iconography, posture, and style of barbarians in imagery had a long existing tradition in numerous instances; however, the blatant isolation of these elements into solitary representations is something that deserves attention. It was not very common to depict only the defeated barbarian. Beyond numismatic imagery on Caesarian coins (Plate 1), there is not much more evidence beyond the Pergamene statues for instances of isolated barbarians. But unlike images on the coins, the barbarian statues are isolated not by way of objectifying them, but through their inherent emotive mood, impacting viewers in a much more emotional, specifically tragic, manner.

Rome had an affinity for tragedy in both textual and visual culture. Tragedy was commonly a focal point in old tragic historiography, Roman theatre, and descriptions of wars. Tragedies were popular in theatre, including famous tragedies of Euripides and adaptations by Roman tragedians, such as Seneca's poignant Herakles Furen. ${ }^{15}$ Influential Greek philosophy in Rome, such as Aristotle's Poetics, described tragedy as an outlet to purge fear, pity, and emotion. ${ }^{16}$ Aristotle criticized tragic historiographers for being sensational in text, not truly writing tragedy. Text could be used to describe or narrate tragedy to a degree, but imagery was the most effective way. In his Mithradaic Wars, Appian describes the tragic paintings of the vanquished; "it was shown how he [Mithradates] died, and the daughters who perished with him were pictured also, and there were figures of the sons and daughters who died before him..."17 Appian also tells of the public's response to such tragic imagery:

\footnotetext{
14 This notion of creative motivation and invention in ancient art is largely based off of dubious concepts of connoisseurship and elitist preference for Greek art emanating from the vastly influential J.J. Winckelmann. His theories, prevalent as they still are, are generally not accepted by current scholars of Roman visual culture.

${ }^{15}$ L. A. MacKay, "The Roman Tragic Spirit," California Studies in Classical Antiquity, 8 (1975), 150.

16 B.L. Ullman, "History and Tragedy," Transactions and Proceedings of the American Philological Association. 73 (1942), 25.

17 Appian, Mithradaic Wars, 17.117.
}

Constellations

Volume 2, No. 2 (Winter 2011) 
"The people... groaned over their domestic ills, especially when they saw the picture of Lucius Scipio, the general-in-chief, wounded in the breast by his own hand, casting himself into the sea, and Petreius committing selfdestruction at the banquet, and Cato torn apart by himself like a wild beast." 18

Tragedy was also a large focal point in Roman visual culture, both mythically and historically. It is worth briefly mentioning a few tragic representations of mythic characters to demonstrate the popularity of the tragic genre and show how critical the Hellenistic style was to portraying tragic figures. One of the most well known tragic figures from myth is the statue of the death of Laocoön and his sons (Plate 16). The terrible emotion shown from the expressive faces and contorted bodies of the three figures emanates tragedy through the mimetic mirroring of human suffering. The facial expression, body contortion, and style of these tragic figures is "quoted" and adapted to the Pergamene barbarians.

Roman visual culture has the agency to evoke response from the viewer and create atmosphere. The Pergamene barbarians embody tragic emotion, remorse, fear, and pity for the defeated, thus forcefully inducing a sympathetic reaction. The most immediate impression of the barbarian statues that impacts the viewer is tragic emotion. An expected, tragic response is clear from posture, facial expression, style, and striking parallels of similar attributes in other known tragic imagery, such as the Laocoön.

Posture of the barbarians highlights the tragic elements of the defeated or dead barbarians. The bodies of the wounded are all close to the ground, about to fall or crouched, shielding themselves. Contortion of defeat is increased through visible wounds on the body. Whereas the Laocoön statue figures are shown receiving their death wounds from the serpents, the barbarian statues are without an enemy; their wounds are already made by an absent, presumably Roman, inflictor and are shown paralyzed by their wound and in their isolation. While the gaze of kneeling Persians and Gauls peer up towards an imaginary oppressor and the viewer in fear and anguish; the gaze of the dying barbarians is downwards staring into their own despair, signalling defeat, shame and humiliation (Plates 11, 15).

Nudity is one other element of these statues which has not received enough attention. Most scholars explain nudity as a semi-heroic device. ${ }^{19}$ Larissa Bonfante, in brief passing over the defeated Gaul barbarians, explains that from an historical perspective, Celtic warriors used to fight naked. ${ }^{20}$ Neither of these suggestions provide a solid reason why the barbarian figures are nude or semi-nude. I believe the answer lies in the subtleties of gender. The concept of gender is flexible and shifts as a social category according to cultural norms. Women in the imagery of warfare appear partially nude, denoting vulnerability, victimization and weakness; images range from epic portrayals of the Rape of Cassandra, to the women on the Gemma Augustae and Column of Marcus Aurelius (Plates 17,18). This same type of nudity is used on the Pergamene barbarian statues to emphasize their vulnerability and subordination, and the

\footnotetext{
18 Appian, Civil Wars, 2.101.

${ }^{19}$ Holscher (2003) 8, Marvin (2002) 212, 221.

${ }^{20}$ Larissa Bonfante, "Nudity as a Costume in Classical Art," American Journal of Archaeology 93, 4 (Oct., 1989), 562.

Constellations
}

Volume 2, No. 2 (Winter 2011) 
application of this gendered visual element adds to the tragic effect. The theatrical reversal of fortune, from heroic nudity to that of degradation, emphasizes the humiliation of total defeat.

The facial expressions of the kneeling and wounded barbarians, with open mouths and furrowed brows, use naturalism to mirror the emotive human condition, conveying fear, surprise, and anguish. These faces possess inherent pathos, while the expression of the dead barbarians imitates the calm of tragic death. Such emotive realism mimetically capturing human emotion in one tangible embodiment creates an atmosphere of tragedy-a sense that visually and emotionally invades the viewers.

Since the establishment of Pax Romana, Rome had gone centuries relatively undisturbed by warfare. By the $2^{\text {nd }}$ century $\mathrm{CE}$, the most commonly agreed date of the barbarian statues, the vast majority of the population led their daily lives centered on the activity and business of the domus, far from concerns of war. Holscher states that in order for Roman victories to be transformed into power of the victors, imagery was used to transmit the idea of war to citizens who have never been involved in combat, allowing the population to participate in them. ${ }^{21}$ However, this is not necessarily straightforward. Since most of the imagery of Roman warfare depicted the triumphant, typically showing the victorious emperors and his soldiers, the average Roman viewer could understand the semiotics of such visual representations of warfare, but he could not experience all the intricacies of such an elevated victory. The average Roman would never experience such an emotional climax like a martial victory. Conversely, the average Roman would have experienced terrible hardship and difficulty. Even though Rome may have not been affected adversely by war, calamity came to the home of every citizen by way of deaths, miscarriage, disease, violence, and crime. ${ }^{22}$

What about imagery of the defeated barbarian? The Pergamene barbarian statues are examples of visual onomatopoeia; they exist in a tragic capacity in the way they are emotionally represented. In one look, they instantaneously express all the components-pain, fear, anguish, helplessness--of tragedy. The viewer sees the tragic emotion within the marble because the emotion exists within the viewer himself. It is the similarities, rather than differences between self and other, Roman and Barbarian, viewer and viewed, which are the most challenging and interesting. ${ }^{23}$ Imagery of warfare from the perspective of the defeated allowed the Roman viewer to experience warfare and its consequences vicariously through figures of extreme mimetic emotion, drawing parallels between self and other. Feelings such as fear and sorrow, tragic emotions, were something common to nearly every individual in Rome. Tragedy is arguably the most prevalent and powerful force on humankind, for it is natural to the human condition to identify with pain, more so than any victory. The barbarian statues and other tragic depictions of the defeated interact with the viewer on an experiential level, invading the psyche, besieging emotion and violently captivating the viewer as he views the violated. It is emotion that is the binding force between Roman viewer and distant barbarian; emotion is universal in its experience, linking the viewer to "all

\footnotetext{
${ }^{21}$ Holscher in Representations of Roman War (2006), 35.

22 Thomas W. Africa, "Urban Violence in Imperial Rome,” Journal of Interdisciplinary History 2, 1 (1971), 7.

${ }^{23}$ Christopher Pelling, "East is East and West is West - Or Are They? National Sterotypes In Herodotus," Histos, 1997.
}

Constellations

Volume 2, No. 2 (Winter 2011) 
those who fell under the wheels of fate and history." ${ }^{24}$ Emotion and atmosphere created by Roman images compel the viewer to experience warfare vicariously through the defeated. Through the harmony and tension created through the depictions of warfare and victordefeated pairs, viewers comprehend the portrayed immensity of glory and power of the Roman army and empire.

I postulate a tentative response on the impact of tragic imagery of war on the Roman viewer. I say tentative because the limited scope of this article leaves an unanswered question whose response is necessary to further understanding of Roman visual culture of warfare: to what extent is the viewer-viewed relationship reciprocal and interactive in the imagery of Roman warfare? Emotion is but one way Roman imagery of warfare communicated through visual culture. Paradox shaped complex interactions between viewer and viewed, Roman and Barbarian, self and other, inversely internalizing the military might of Rome through identification with the emotion and subordination of the defeated. The reflection of self in other, and other in self is made possible through the mimetic mirror reflecting the truth of emotion between barbarian and viewer, ${ }^{25}$ and if that mirror reflects truth, then it is a window that transparently lends agency to the viewer's perception of naturalism and the viewed's fantasy of reality, essentially binding them to a collective humanity that is, above all, pervasive in consciousness.

${ }^{24}$ Holscher (2004), 32.

25 Pelling, 1997. 


\section{Bibliography}

Africa, Thomas W. "Urban Violence in Imperial Rome." Journal of Interdisciplinary History 2, 1. 1971. 321.

Appian. Mithradaic Wars. trans. Horace White. Loeb Classical Library, 1913. http://www.livius.org/ap-ark/appian/appian_mithridatic_00.html

---. Civil Wars. http://penelope.uchicago.edu/Thayer/E/Roman/Texts/Appian/home.html

Bal, M. \& N. Bryson. "Semiotics and Art History." The Art Bulletin 73, 2. 1991. 174-208.

Bonfante, Larissa. "Nudity as a Costume in Classical Art." American Journal of Archaeology 93, 4. 1989. 543-570.

Dillon, Sheila and Katherine E. Welch, Eds. Representations of War in Ancient Rome. New York: Cambridge University Press. 2006.

de Grummond, Nancy T. and Brunilde S. Ridgway, Eds. From Pergamon to Sperlonga: Sculpture and Context. Berkley: University of California Press. 2000.

Elsner, Jan. Roman Eyes: Visuality and Subjectivity in Art and Text. Princeton: Princeton University Press. 2007.

Hijmans, Steven. Sol: The Sun in the Art and Religions of Rome. PhD diss., Groningen University. 2009.

Holscher, Tonio. The Language of Images in Roman Art. Trans. Anthony Snodgrass and Annemarie Kunzl-Snodgrass. New York: Cambridge University Press. 2004.

---. "Images of War in Greece and Rome: Between Military Practice, Public Memory, and Cultural Symbolism." The Journal of Roman Studies 93. 2003. 1-17.

Kampen, Natalie Boymel. "On not writing the History of Roman Art." The Art Bulletin 77. 1995. 371 386.

Kuttner, Ann. "Republican Rome Looks at Pergamon." Harvard Studies in Classical Philology 97. 1995. 157-178.

MacKay, L. A. "The Roman Tragic Spirit.” California Studies in Classical Antiquity 8. 1975. 145-162.

Marvin, Miranda. "The Ludovisi Barbarians: The Grand Manner." Memoirs of the American Academy in Rome. Supplementary Volumes 1. 2002. 205-223.

Mitchell, W.J.T. Iconology: Image, Text, Ideology. Chicago: University of Chicago Press. 1986.

Panofsky, E. Meaning in the Visual Arts. Chicago: University of Chicago Press. 1955.

Pelling, Christopher. "East is East and West is West - Or Are They? National Stereotypes in Herodotus.” Histos. 1997. http://www.dur.ac.uk/Classics/histos/1997/pelling.html

Platner, Samuel Ball. A Topographical Dictionary of Ancient Rome. London: Oxford University Press. 1929. Lacus Curtius Educational Resource, http://penelope.uchicago.edu/Thayer/E/Gazetteer/Places/Europe/Italy/Lazio/Roma/Ro me/_Texts/PLATOP*/home*.html

Stewart, Andrew. Attalos, Athens and the Akropolis: The Pergamene Little Barbarians' and their Roman and Renaissance legacy. New York: Cambridge University Press. 2004.

Ullman, B.L. "History and Tragedy." Transactions and Proceedings of the American Philological Association 73. 1942. 25-53. 


\section{List of Plates}

1. Roman. Julius Caesar. Classical Numismatic Group. Inventory number: 75, 920. 46-5 BCE. Denarius.Venus/Trophy of defeated Gauls. Source: http:/ $/$ www.acsearch.Info $/$ search.html?search $=\& v i e w \_m o d e=0 \& c=12 \& a=239 \& l=\& p a g e=$ 37

2. Vienna. Kunsthistorisches Museum. Inventory number IX A79 Gemma Augustae. Roman, from Rome: 9-12

CE. Onyx in setting of gold frame. Photo: unknown. Source: http://www.carotta.de/subseite/events/lhc_e.html

3. Naples, Museo Nazionale. Inventory number 10020. Alexander Mosaic. Roman, from House of the Faun, Pompeii; original painting ca. 300-300 BCE. Photo: DAI Rome 58.1448. Source: Stewart, Attalos, Athens and the Akropolis, 2004.

4. Gemma Augustae. Photo: unknown. Source: http://www.laits.utexas.edu/moore/rome/image/gemma-augustea-0

5. Vatican, Galleria dei Candelabri. Inventory Number 2794. Persian. Roman, from Rome: originals, ca. 200 BCE. Marble. Photo: A. Stewart. Source: Andrew Stewart, Attalos, Athens and the Akropolis: The Pergamene 'Little Barbarians' and their Roman and Renaissance legacy, New York: Cambridge University Press, 2004.

6. Paris, Musee de Louvre Inventory Number Ma 324. Paris Gaul. Roman, from Rome; originals, ca. 200 BCE. Marble. Photo: Chuzeville. Image Source: Stewart, Attalos, Athens and the Akropolis, 2004.

7. Venice, Museo Archeologico. Inventory Number 55.Venice Falling Gaul. Roman, from Rome;originals, ca. 200 BCE. Marble. Photo: Osvaldo Bohm. Image Source: Stewart, Attalos, Athens and the Akropolis, 2004

8. Venice, Museo Archeologico. Inventory Number 57. Kneeling Gaul. Roman, from Rome; original ca. 200 BCE. Marble. Photo: Osvaldo Bohm. Image Source: Stewart, Attalos, Athens and the Akropolis, 2004

9. Plate 5.5. Venice, Museo Archeologico. Inventory Number 56. Dead Gaul. Roman, from Rome; originals, ca. 200 BCE. Marble. Photo: Osvaldo Bohm. Image Source: Stewart, Attalos, Athens and the Akropolis, 2004.

10. Naples, Museo Nazionale inventory number 6104. Persian, Roman, from Rome; originals, ca. 200 BCE. Marble. Photo: Alinari/Art Resource 5270. Image Source: Stewart, Attalos, Athens and the Akropolis, 2004.

11. Naples, Museo Nazionale inventory number 6015. Dying Gaul, Roman, from Rome; originals, ca. 200 BCE. Marble. Photo: Alinari/Art Resource 5270. Image Source: Stewart, Attalos, Athens and the Akropolis, 2004.

12. Naples, Museo Nazionale inventory number 6012. Amazon, Roman, from Rome; originals, ca. 200 BCE. Marble. Photo: Alinari/Art Resource 5270. Image Source: Stewart, Attalos, Athens and the Akropolis, 2004.

13. Naples, Museo Nazionale inventory number 6012. Amazon, Roman, from Rome; originals, ca. 200 BCE. Marble. Photo: Alinari/Art Resource 5270. Image Source: Stewart, Attalos, Athens and the Akropolis, 2004. 
14. Rome, Museo Nazionale Romano Palazzo Altemps. Inventory number 8608. Suicidal Gaul and his wife. Roman, from Rome: original ca. 230-200 BCE. Marble. Photo: Soprintendenza Archeologica di Roma 188 241. Image Source: Stewart, Attalos, Athens and the Akropolis, 2004.

15. Rome, Museo Capitolino. Inventory Number 747. Dying Gallic Trumpeter. Roman, from Rome: original ca. 230-2000 BCE. Marble. Photo: Soprintendenza Archeologica di Roma. Image Source: Stewart, Attalos, Athens and the Akropolis, 2004.

16. Vatican, Cortile del Belvedere. Inventory Number 1059, 1064, 1067. Laokoon and his two sons. From Rome; ca. 40 BCE or later. Restored in 1950's by Filippo Magi. Photo: Vatican museums XXXIV.22.9. Source: Stewart, Attalos, Athens and the Akropolis, 2004.

17. "The Fall of Troy," with detail of Cassandra and Ajax. Pottery attributed to the Kleophrades Painter, c. 480 BCE.

http://www.arthistory.sbc.edu/imageswomen/papers/fittoncassandra/analysis.html

18. Rome. Column of Marcus Aurelius, detail of a barbarian woman and child, and Roman soldier. Late $2^{\text {nd }}$ century. Photo: unknown. Source: Sheila Dillon and Katherine E. Welch, Eds, Representations of War in Ancient Rome, New York: Cambridge University Press, 2006. 

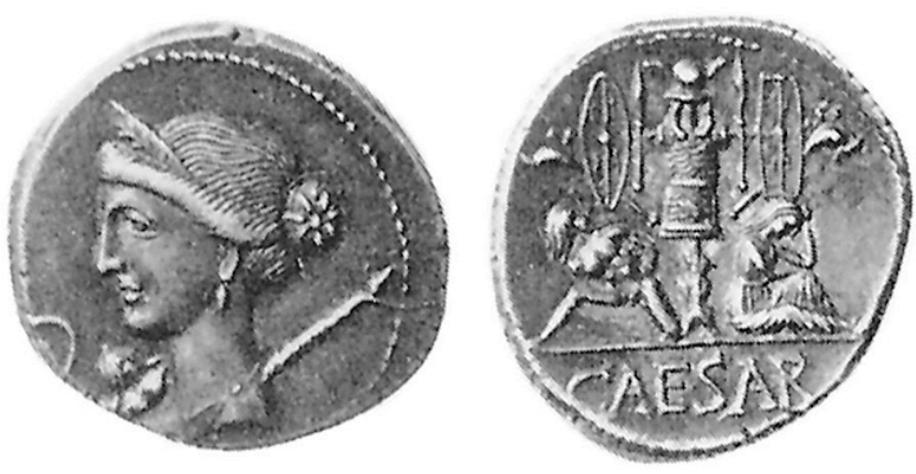

\section{Plate 1}

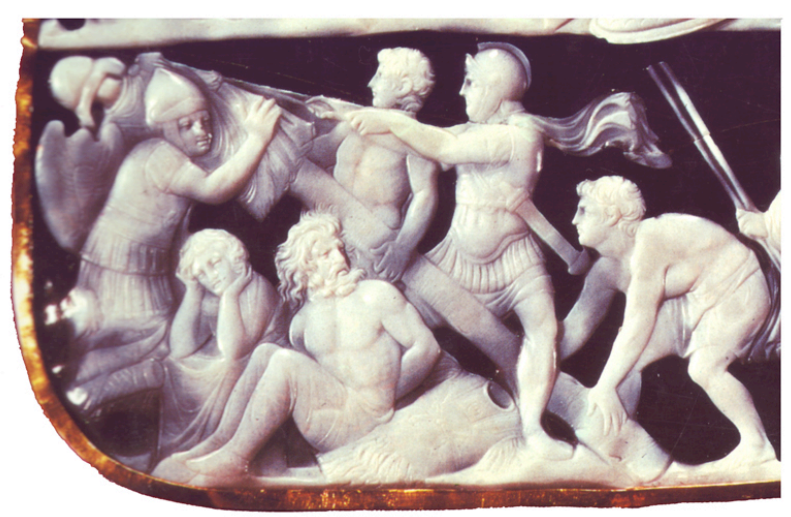

Plate 2

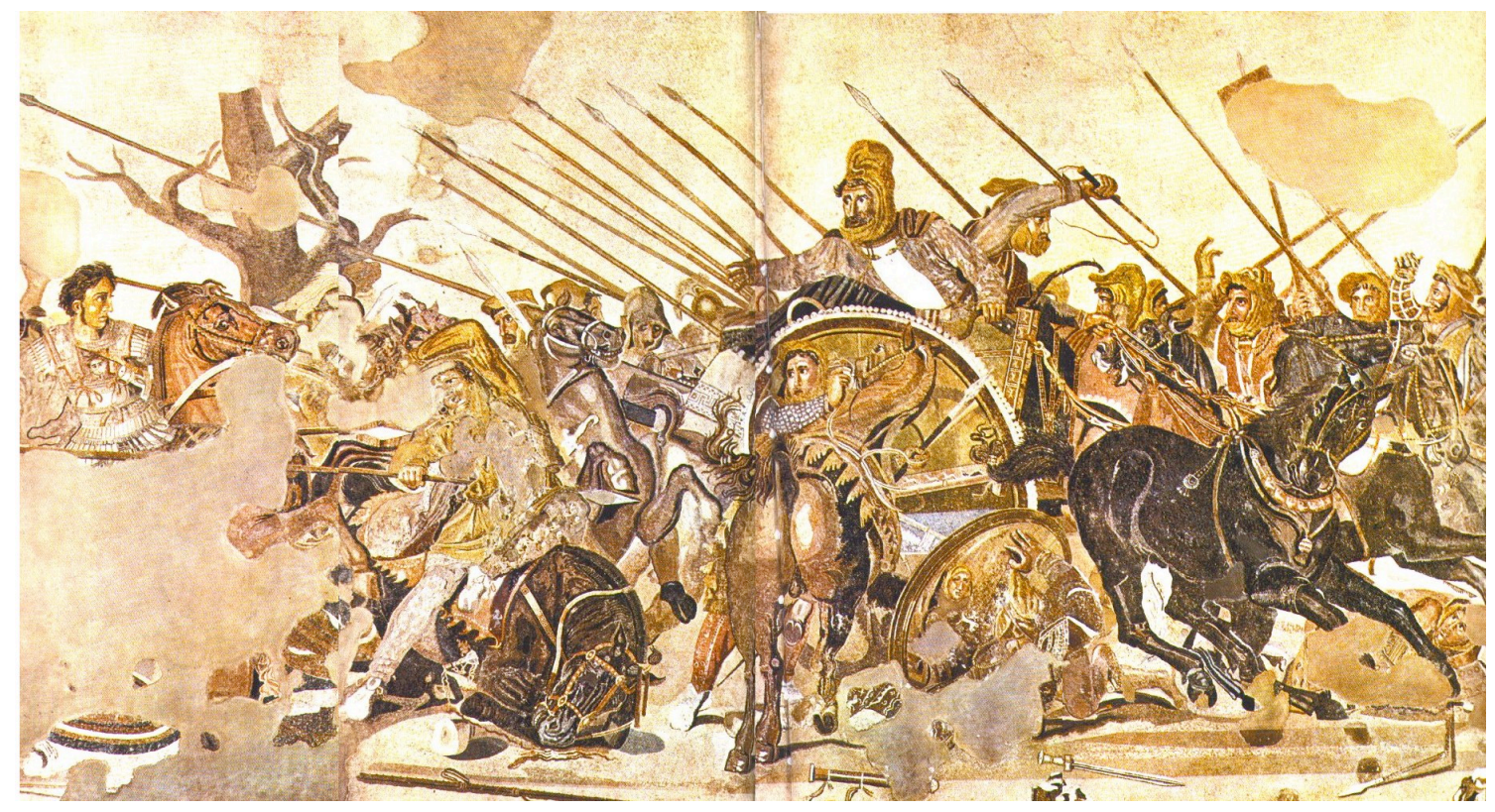

Plate 3 


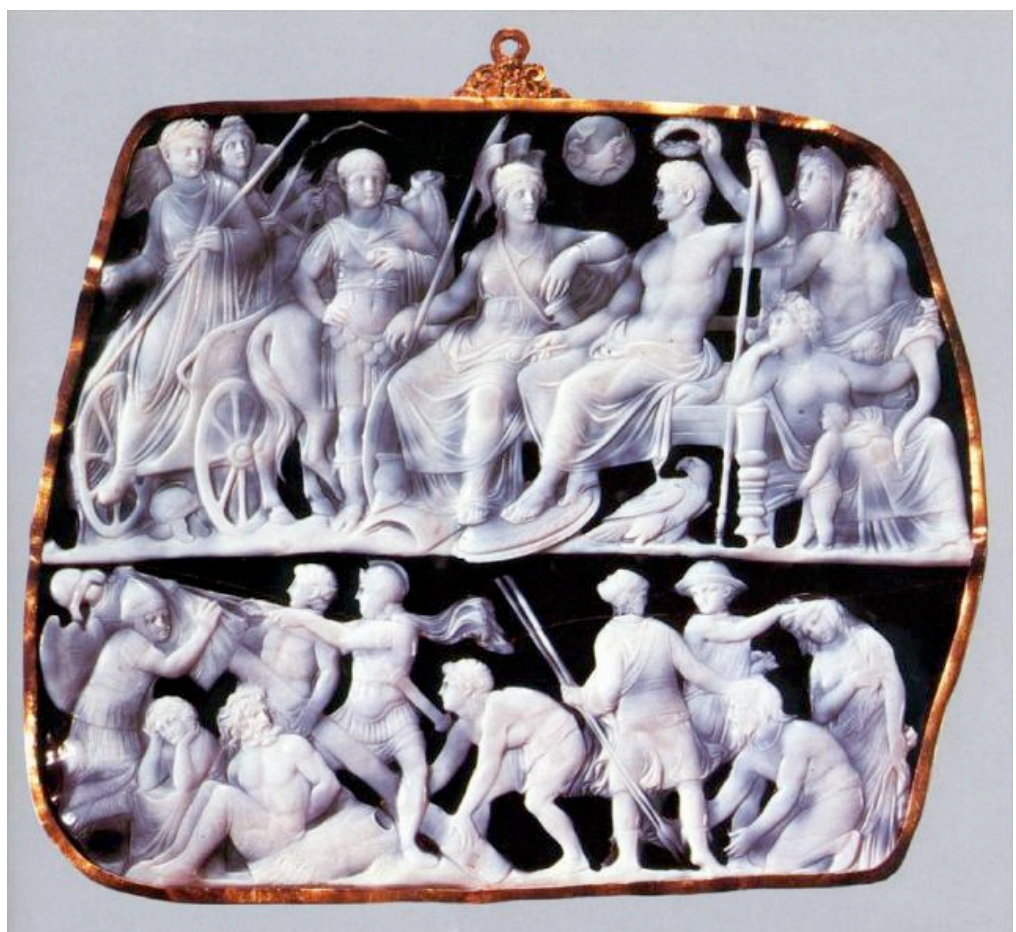

Plate 4

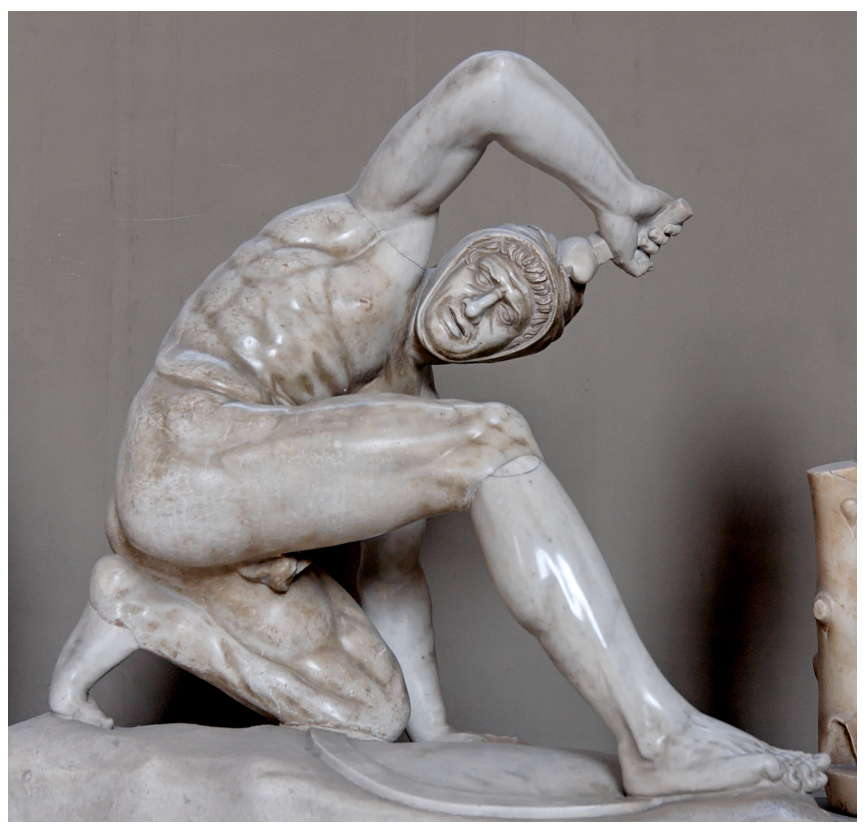

Plate 5 


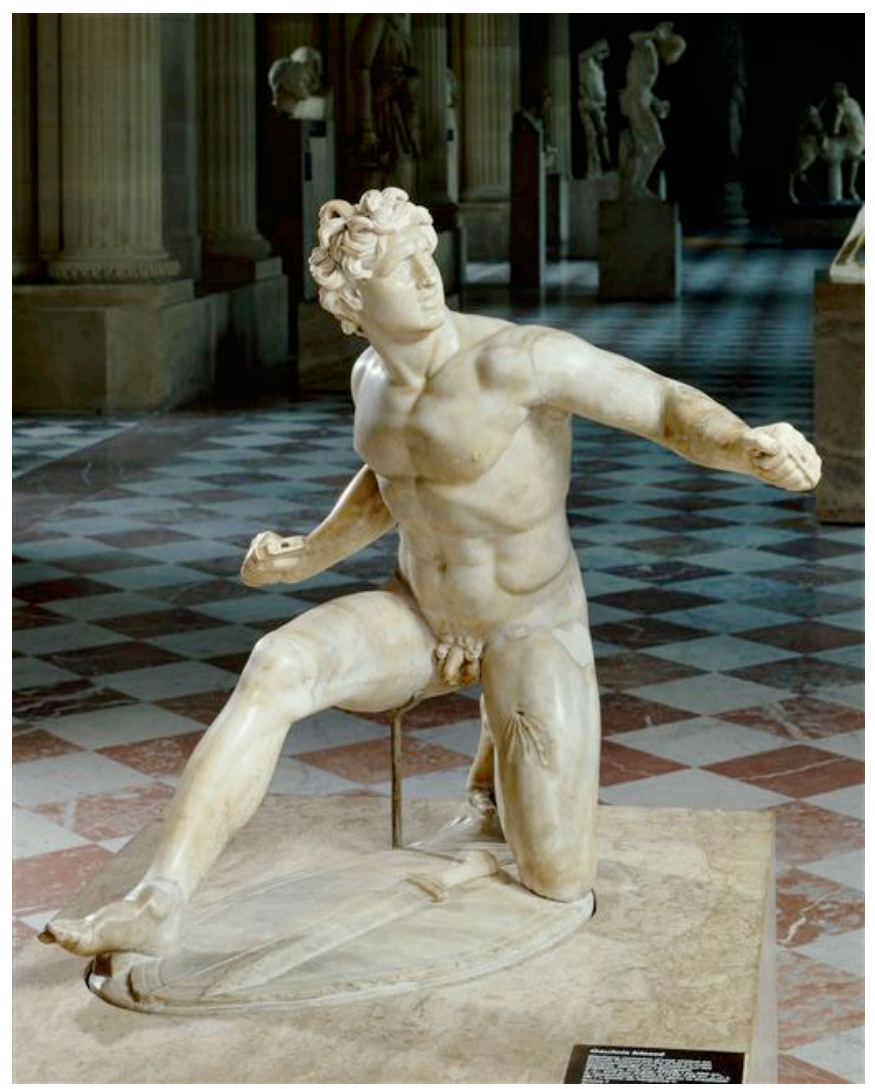

Plate 6

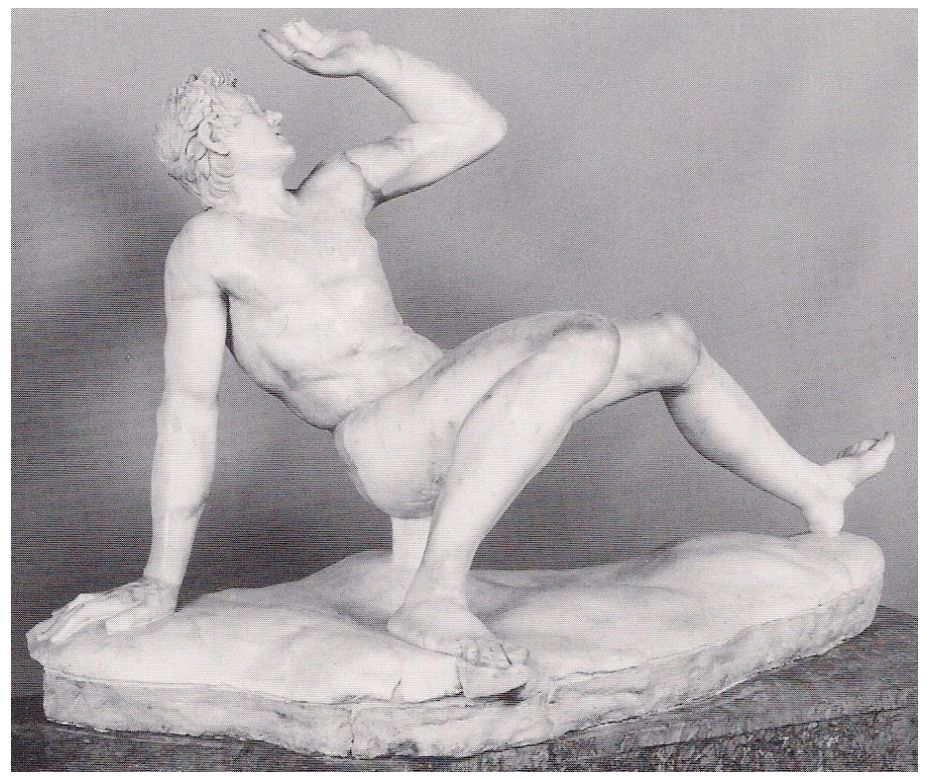

Plate 7 


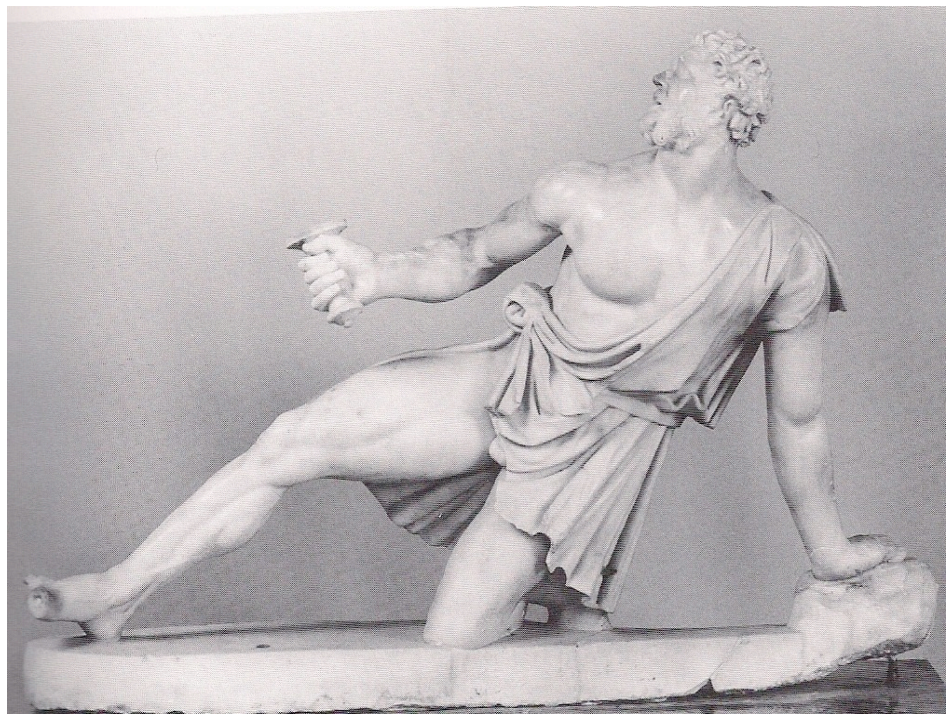

Plate 8

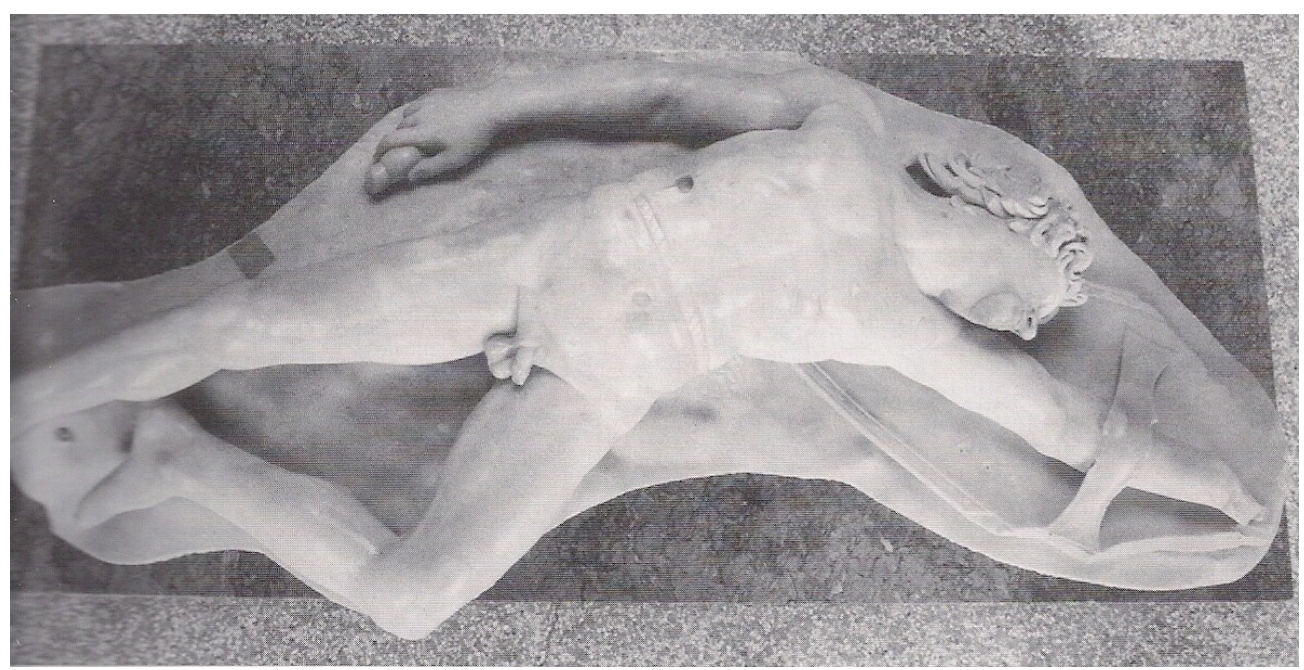

Plate 9 


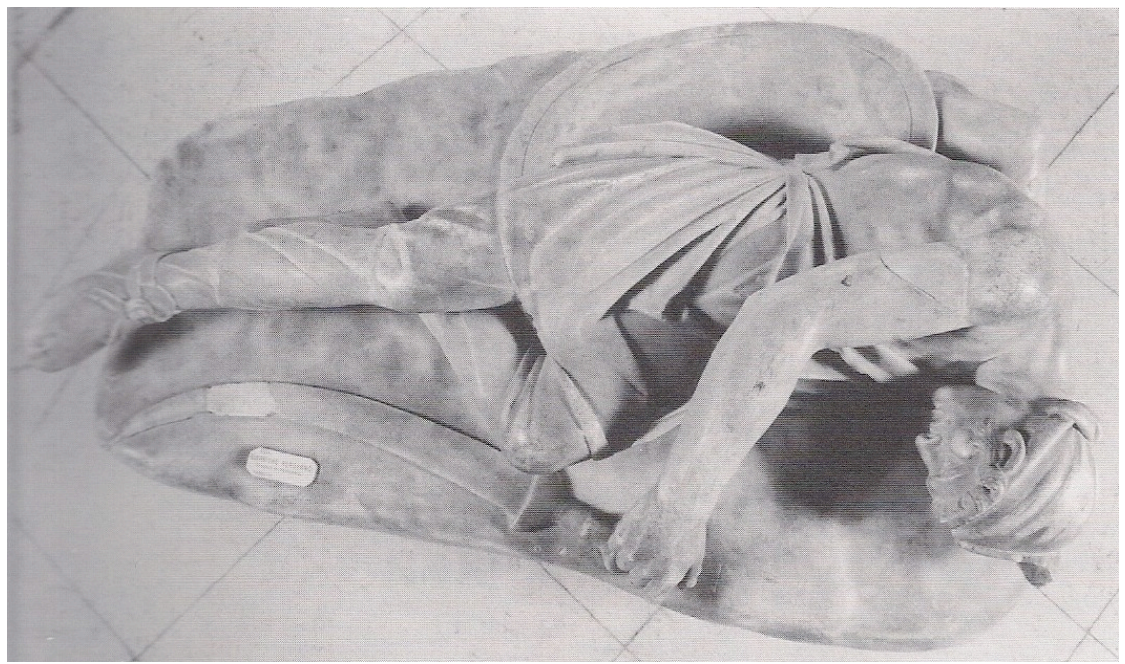

Plate 10

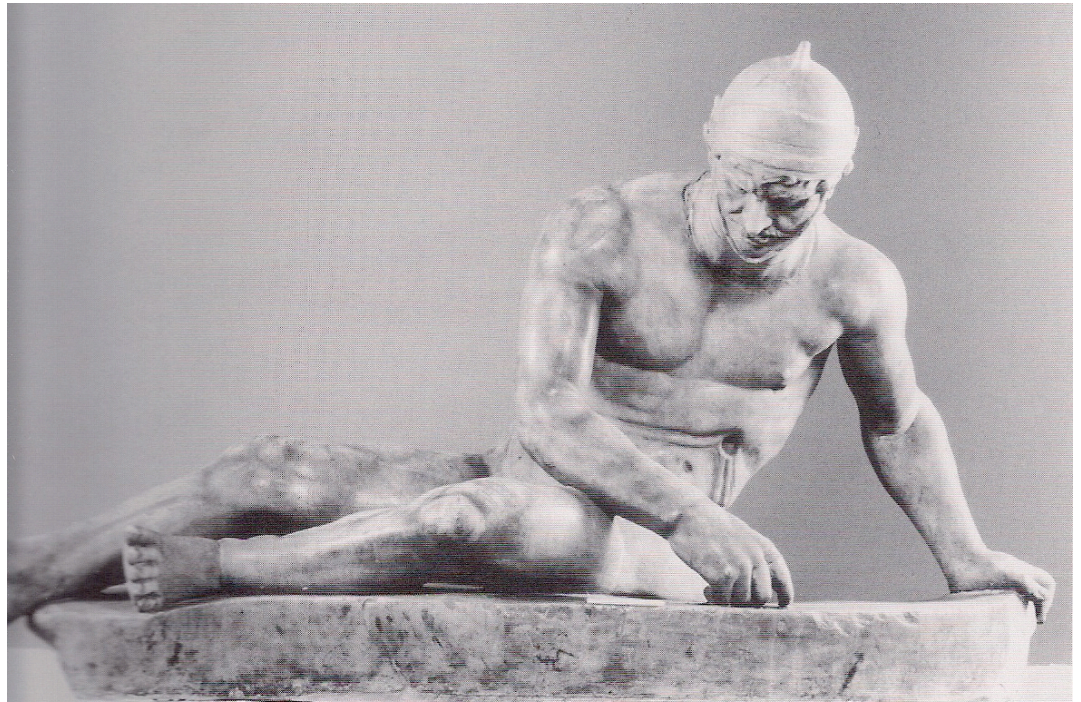

Plate 11 


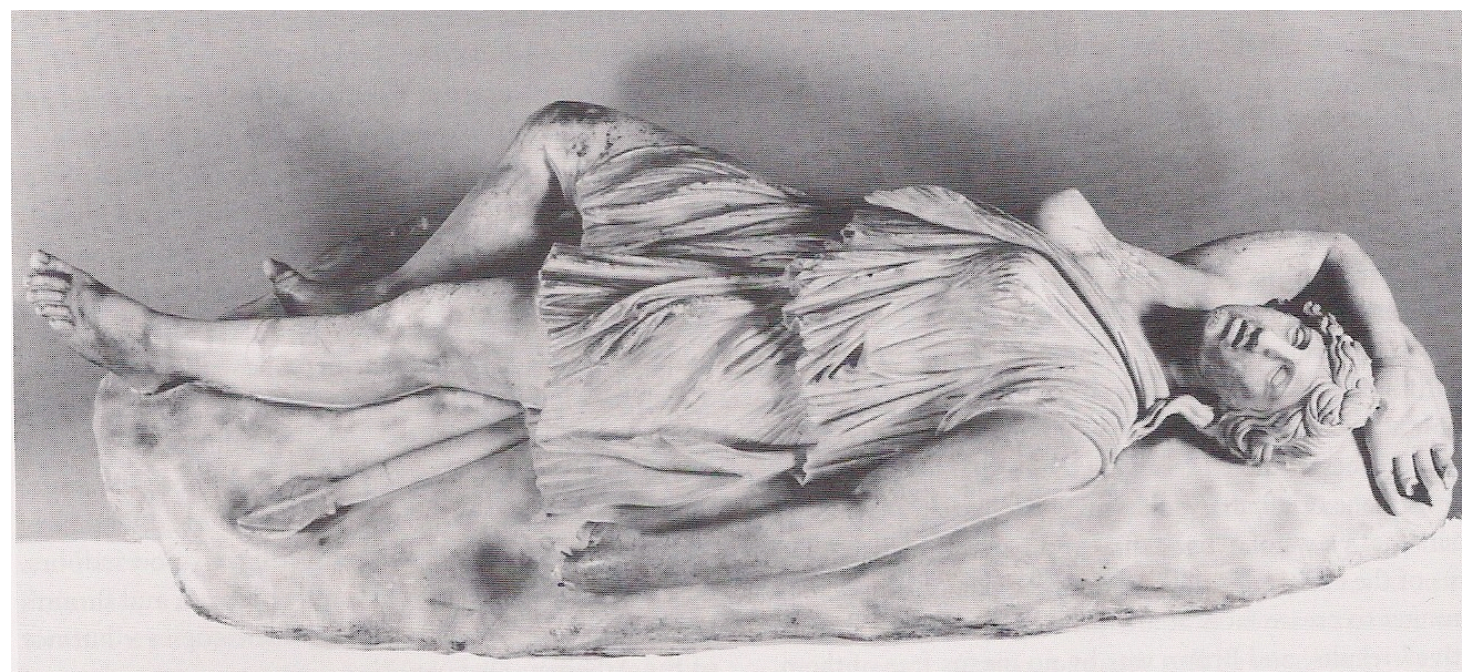

Plate 12

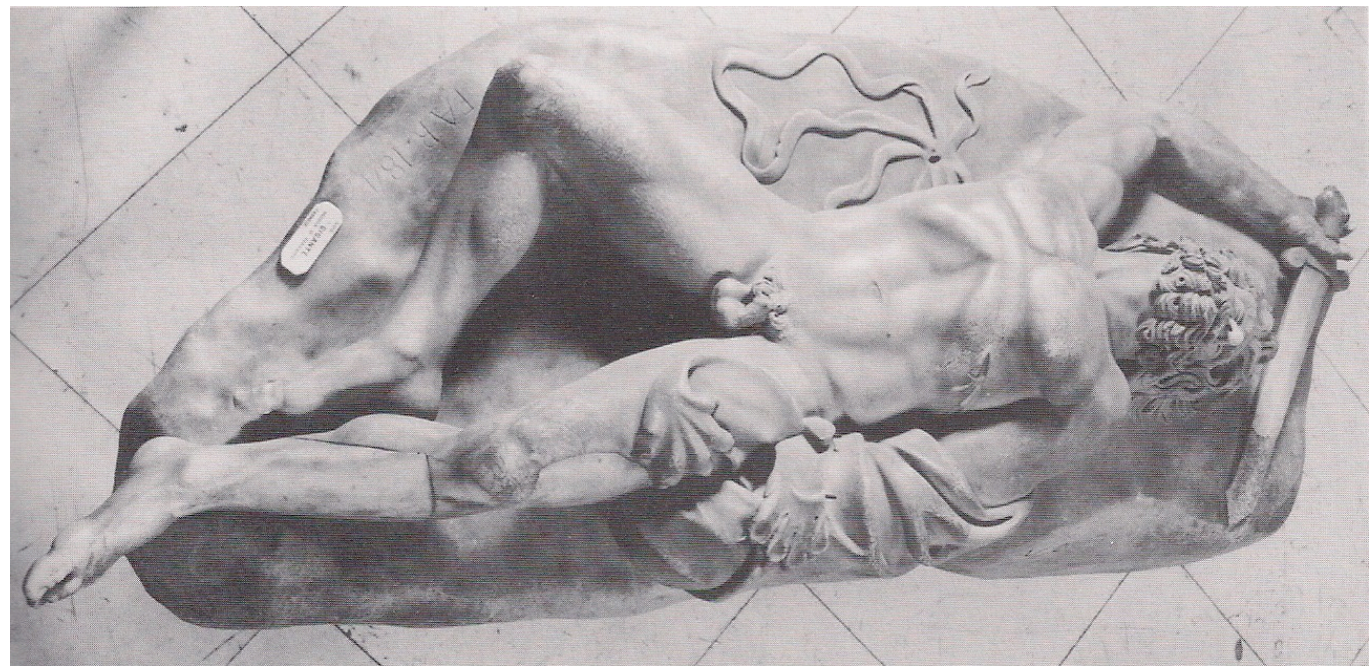

Plate 13 


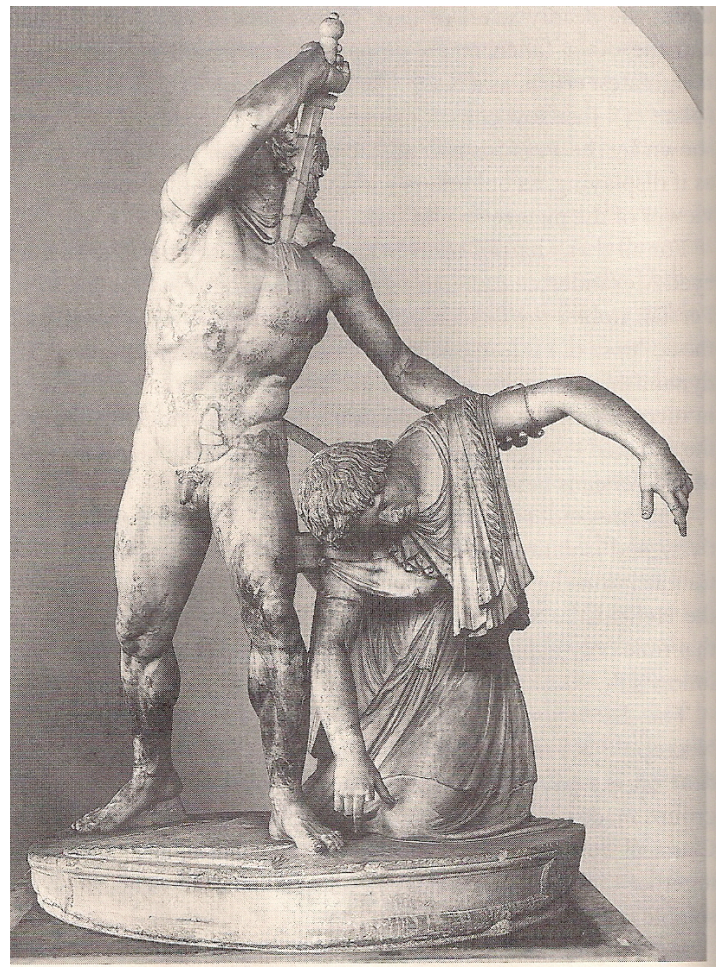

\section{Plate 14}

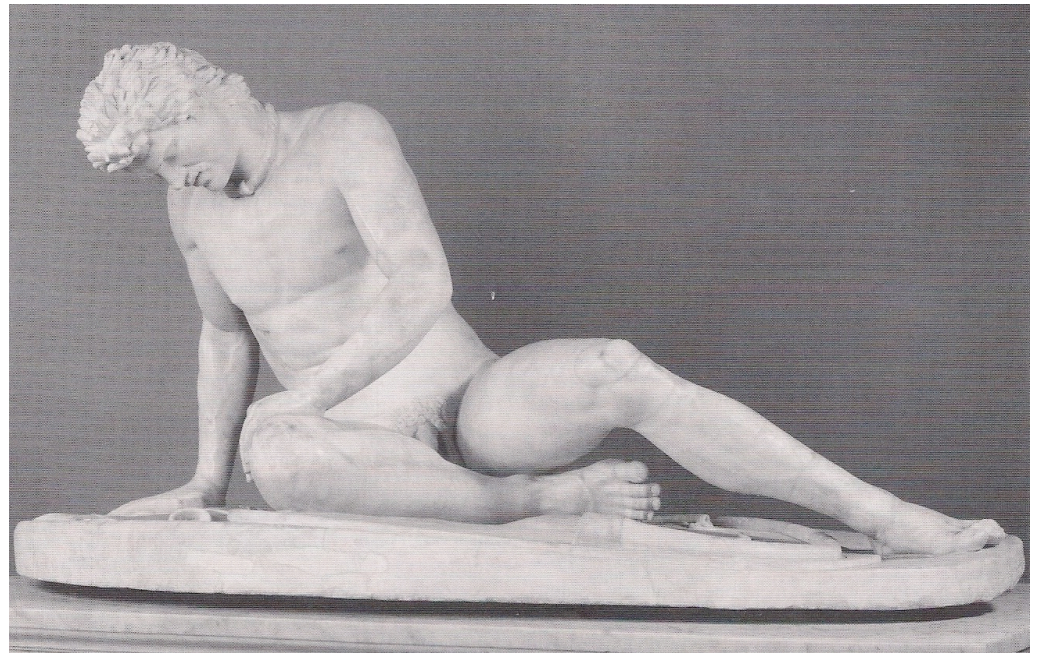

Plate 15 


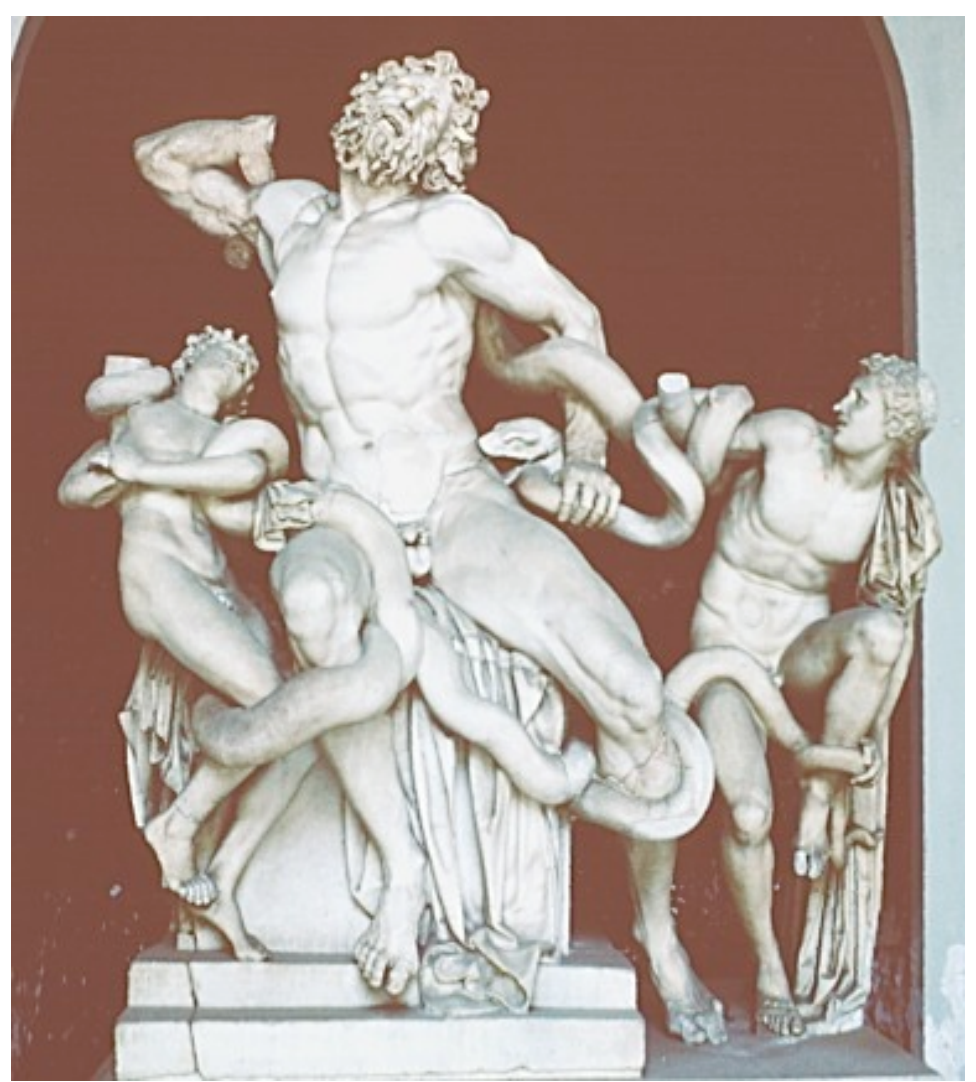

Plate 16

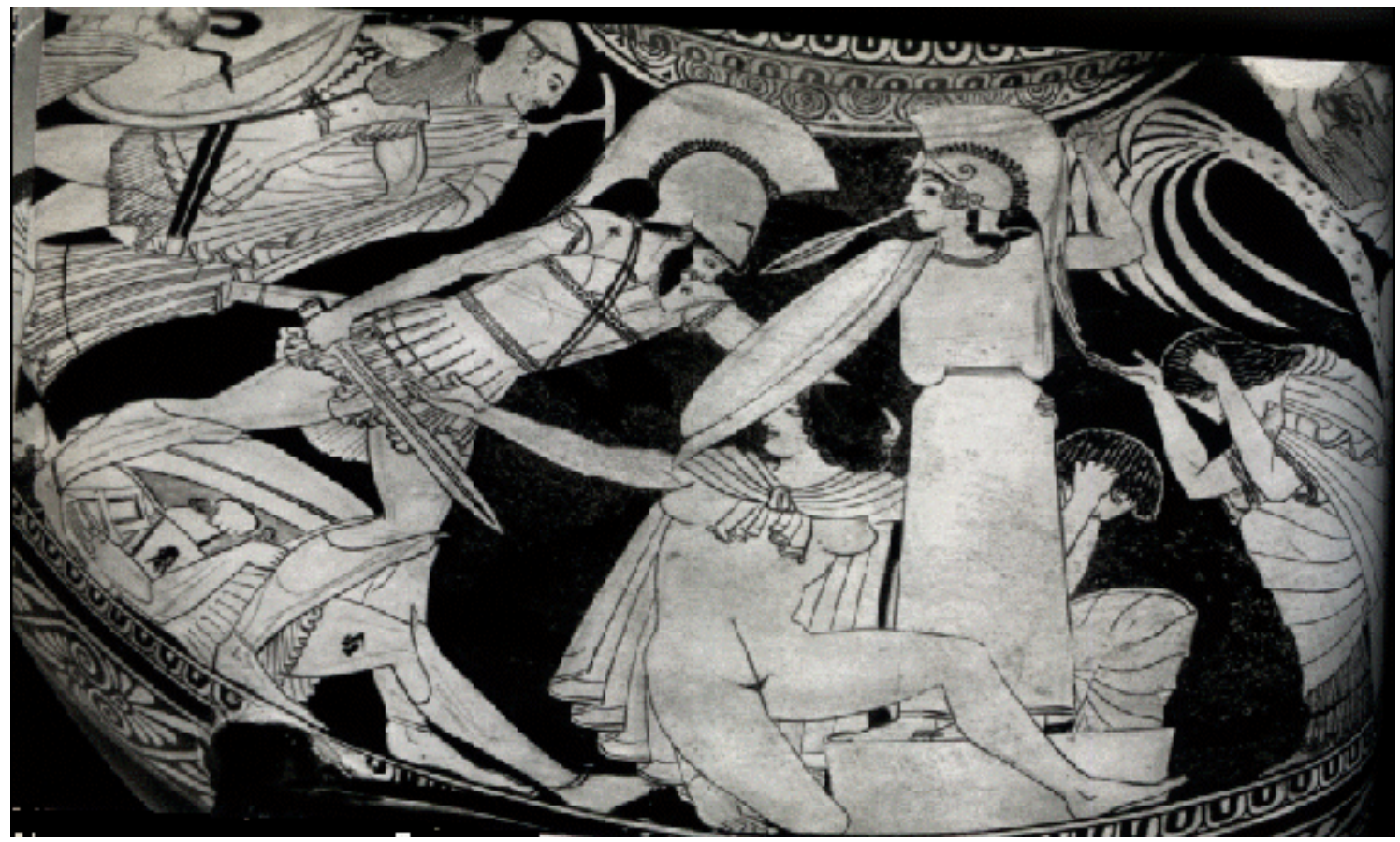

Plate 17

\section{Constellations}

Volume 2, No. 2 (Winter 2011) 


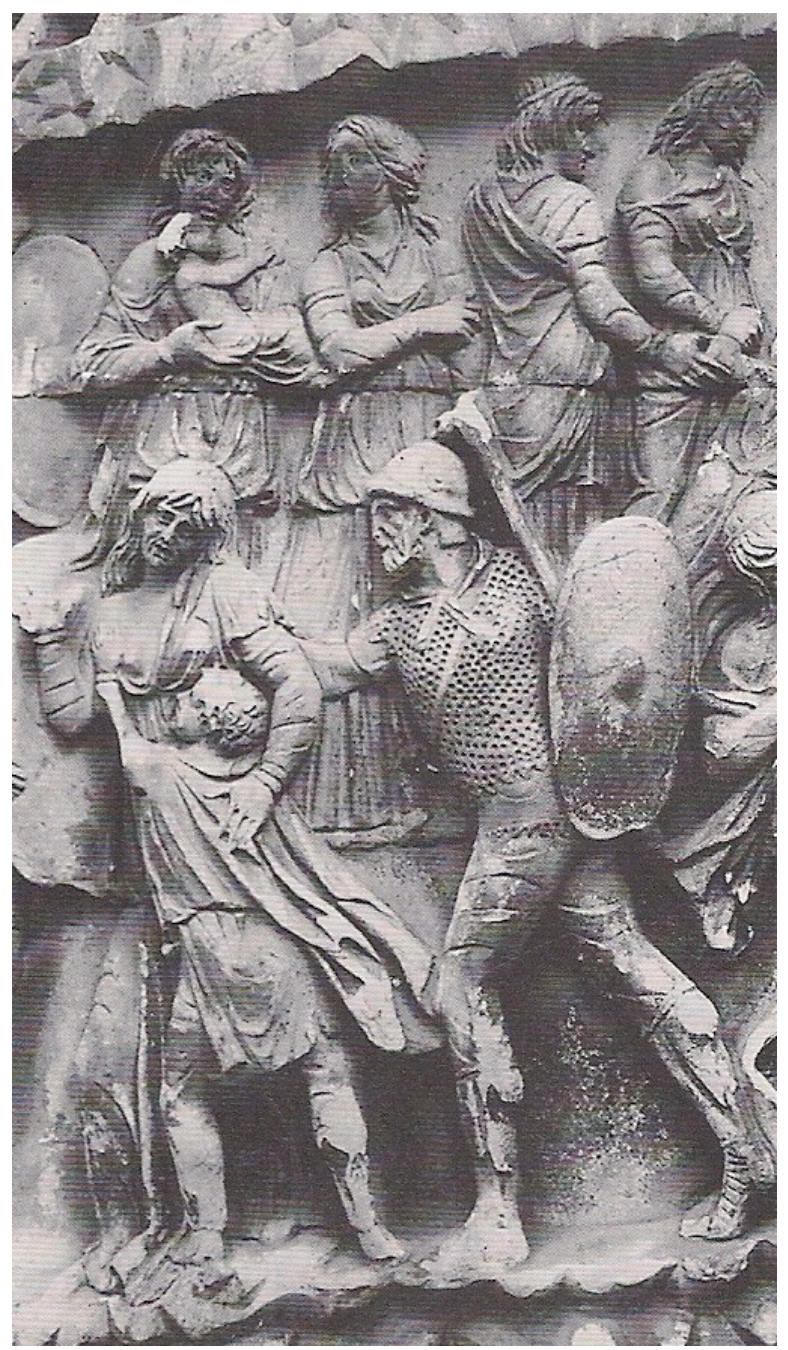

Plate 18 